AperTO - Archivio Istituzionale Open Access dell'Università di Torino

Occupational Regulation in the European Union: Coverage and Wage Effects

This is a pre print version of the following article:

Original Citation:

Availability:

This version is available http://hdl.handle.net/2318/1706360

since 2020-02-05T13:48:33Z

Published version:

DOI:10.1111/bjir.12441

Terms of use:

Open Access

Anyone can freely access the full text of works made available as "Open Access". Works made available under a Creative Commons license can be used according to the terms and conditions of said license. Use of all other works requires consent of the right holder (author or publisher) if not exempted from copyright protection by the applicable law. 


\title{
Occupational Regulation in the European Union: Coverage and Wage Effects
}

\begin{abstract}
We present the first EU-wide study on the prevalence and labour market impact of occupational regulation in the EU. Drawing on a new EU Survey of Regulated Occupations, we find that licensing affects about 22 percent of workers in the EU, although there is significant variability across member states and occupations. On average, licensing is associated with a 4 percent higher hourly wages. Using decomposition techniques, we show that rent capture accounts for one third of this effect and the remaining is attributed to signalling. We find considerable heterogeneity in the wage gains by occupation and level of educational attainment. Finally, occupational licensing increases wage inequality. After accounting for composition effects, licensing increases the standard deviation of wages by about $0.02 \log$ points.
\end{abstract}

Word Count: 9,792

JEL codes: J44, J31, G18

Keywords: Occupational regulation, licensing, wages. 


\section{Introduction}

Occupational regulation is a labour market institution that has attracted considerable debate within academic and policy cycles. The current policy interest derives from its potential to serve as a strong incentive for employers and workers to invest more heavily in skills and as a means to address information asymmetries. However, economists have also warned about the potentially negative labour market effects of regulation that can result from the rent-seeking activities of occupational groups (e.g. Maurizi 1974; Shapiro 1986). While there is now a welldeveloped empirical literature in the US assessing the labour market outcomes of occupational regulation, the paucity of such evidence in the European context is striking. This is a surprising omission given that, as we shall show below, entry to a significant proportion of EU jobs is restricted through the imposition of minimum competency standards to lawfully practice for pay (known as licensing). As such, the importance of this labour market institution extends beyond academic curiosity and deserves more attention than it currently receives. Less common in empirical analyses is the study of the effect of certification. Certification offers practitioners the option to join a scheme that verifies that their skills meet certain standards. Contrary to licensing, while these schemes can signal competency, they do not impose any legal restrictions on the right to practice. Nevertheless, these gaps in the literature are not entirely unjustifiable. Since recently, researchers in Europe have lacked comprehensive data that identifies regulated individuals, the characteristics of the regulatory regime they are subject to and their individual and labour market characteristics. This paper addresses this gap. We explore the first ever EU Survey of Regulated Occupations (EU-SOR); a survey consisting of a representative sample that covers the labor force within the EU28 member states and asks detailed questions about occupational regulation. We are interested in three key themes: incidence of regulation in the EU labour market, its effect on wage determination and its effect on wage inequality.

Prior to EU-SOR, researchers have been restricted to imputing the regulation status of a worker based on her reported occupation (e.g. Gittleman and Kleiner 2016; Koumenta et al. 2014). While informative, the precision of this procedure is likely to be compromised by the possibility that some of those classified as working in a licensed occupation are in fact not 
licensed. For example, an engineer working in a multinational company in the automotive industry might not need to be licensed, although the engineering profession is generally subject to licensing. This highlights the difference between coverage and individual attainment of licensed status. Moreover, the codes commonly used to classify occupations do not necessarily describe licensed professions, as defined by licensing regulations. By explicitly asking the respondents to report their regulation status, EU-SOR enables us to address this measurement problem. In this paper, we contribute to the literature in three ways. First, we provide the first ever EU estimates of the prevalence of occupational regulation in the EU and estimate the wage premium associated with licensing (the most restrictive form of regulation) and certification (its less restrictive counterpart). Second, we decompose the wage premium using the OaxacaBlinder decomposition and in doing so, provide more systematic estimates of the wage gap between licensed and non-licensed workers than currently available in the extant literature. Third, we contribute to a less well-developed line of enquiry in the study of occupational regulation, namely the impact of licensing on the wage distribution. We do so using the Di Nardo, Fortin and Lemieux (1996) decomposition method, which is itself a new approach to estimating such effects within the occupational regulation field. Throughout our analysis, we compare our findings with those in the US, where the literature is more advanced, to establish any differences or similarities between these two labour market contexts.

\section{Related Literature}

Entry requirements associated with licensing regulate the supply and deployment of labour in the market. This is achieved in two ways. First, entry to the occupation is restricted to those practitioners whose skills or character are above the minimum requirements. Second, regulators may revoke the license if performance of incumbents is deemed to fall short of meeting the professional standards. The implication of these arrangements is that the entry requirements associated with licensing reduces the pool of practitioners thus potentially creating monopoly rents within the occupation (Pagliero 2013; 2011; 2010). As such, the wage effect of regulation is borne by the artificial creation of entry barriers in the occupation, as opposed to the standard human capital returns in the labour market. Research on the wage effect of regulation has a relatively long tradition, but improvements in measurement have resulted in two empirical developments: (i) better estimations of the wage premium associated with licensing (ii) detection of potential differential effects of licensing on wage determination by occupation. 
With regards to the former, using a self-reported measure of regulation status, Kleiner and Krueger (2013) find its effect on wages to be around the $11 \%$ mark in the US. Gittleman and Kleiner (2016) exploit the introduction of questions on occupational regulation in large-scale national surveys. Using longitudinal data and a rich set of labour market controls, they find wage effects considerably lower than previous estimates (of about 7.5\%). Further, early studies present licensing as having a homogeneous wage effect, without any differentiation by occupation or licensing regimes. More recently, researchers have considered the possibility of heterogeneity in the effect of licensing on wages. According to Kleiner (2013), the ability of occupations to capture rents depends on factors associated with the political economy of the regulatory regime, such as the strictness of entry barriers or the amount of time the occupation has been subject to regulation. Indeed empirically, it has not been uncommon to observe occupational variations on the wage effect of licensing. For example, Timmons and Thornton use a cross-state U.S. survey of radiologic technologists and find the wage effect of licensing to be $6.9 \%$ (Timmons and Thornton 2007), while the same figure for massage therapists stands at $16.2 \%$ (Timmons and Thornton 2013). In his comparison of average incomes across licensed and non-licensed occupations, Kleiner (2000) calculates the licensing premium among dentists, and lawyers vis-à-vis other comparable occupations. Despite many similarities in the educational licensing requirements for dentists and lawyers, the wage effect is $30 \%$ for the former and $10 \%$ for the later. In the UK context too, Koumenta et al. (2014) find significant variations in the wage premium amongst dentists, pharmacists, accountants, architects, security guards, teachers and plumbers (ranging from 9\% to 19\%). Although these studies allude to potential heterogeneity in the effect of licensing on wages, they fall short of a systematic examination by occupational classification. Finally, our data source enables us to go even further in understanding the effect of regulation in the labour market by examining its effect on returns to education. Does licensing create a distortion in the returns to education and if so, how does this pattern vary by the level of educational attainment?

Less common in the literature is the study of the impact of licensing on different parts of the income distribution. Licensing can result in the creation of rents through the monopoly effect discussed above. If they are unequally distributed amongst income groups, economic rents can aggravate income inequality, such that those at the top of the income distribution fare better than those at the bottom. Empirically, such a line of enquiry parallels the study of the effect of unionism (another labour market institution associated with rent-capture) on wage dispersion. For example, in his classic work on the effects of unions, Freeman (1991) finds that despite the 
inequality-increasing effect of unions on the difference between union members and nonmembers, the overall effect of unions on income inequality is negative. Does licensing have a similar effect on wage dispersion? Recent analyses by Kleiner and Krueger (2013) and Gittleman and Kleiner (2016) for example find that licensing does not reduce wage dispersion in the US labour market.

As a policy alternative to licensing, certification is less restrictive in that it presents consumers with a choice between practitioners whose credentials have been vetted by the state or a professional body. In theory, we would expect its effect on wages to depend on the restrictiveness of the entry criteria pertaining the certification regime, the extent to which consumers are willing to pay a premium for practitioners meeting these standards and the degree to which state involvement in its operation entails rigorous vetting of applicants and monitoring of standards (Forth et al. 2011). In the US, Gittleman et al. (2018) estimate that certified workers earn approximately $7.5 \%$ higher wages than their unlicensed and uncertified counterparts, while Kleiner and Krueger (2013) find positive but not statistically significant coefficients for certification in their various specifications.

\section{The survey and the sample}

The data used for this study is based on the EU-SOR, the first ever survey commissioned by the European Commission dedicated to capturing the extent of occupational regulation in the EU. The questionnaire items are drawn from questions successfully tested in the US-based Westat survey of regulated occupations (Kleiner and Krueger 2013), and further developed to suit the specific research context. To test the final instrument, a pilot study was carried out which suggested some revisions to the questionnaire, including shortening its length and some minor adjustments to the item wording.

The survey covers the civilian population of the respective nationalities of the EU member states, resident in each of the 28 member states, aged 15 years and over who at the time were working or looking for a job. The survey was carried out in the period between March to April 2015 by means of telephone interviews (Computer Assisted Telephone Interviews) using a multi-stage random probability sample design. In every country, respondents were called on fixed lines and mobile phones, and in each household the respondent was drawn at random following the 'last birthday rule'. 
A total of 26,640 individuals were interviewed providing data on their regulation status, the characteristics of the regulation regime (e.g. entry and renewal requirements), as well as detailed information on a variety of individual characteristics. ${ }^{i}$ The data has several important strengths for our analysis. In addition to providing us with a self-reported measure of the regulation status of the individual, the large sample size increases the external validity and precision of our estimates, while the breadth of information about individuals and their labour market circumstances improves our ability to control for observable heterogeneity that might be correlated with regulation status and earnings.

The response rate was $28 \%$. The response rate is higher than the $17.9 \%$ obtained by Westat, its American counterpart (Kleiner and Krueger 2013), analogous to that of commercial surveys and in a context of declining response rates to telephone surveys (see for example Curtin et al. 2005 ) overall very satisfactory. We proceed to examine the credibility of our data by comparing the mean proportion of respondents in the EU-SOR with those reported in the EU Labour Force Survey (EULFS) for the same year (Table 1). In Column 3, we estimate the difference in the means across a range of indicators relating to individual and labour market characteristics. Differences are below 1 percent for gender, age, and employment type groups. However, the EU-SOR sample includes 4 percent less workers with secondary education and 6 percent more with tertiary education than the Eurostat data. Differences by industry are below 1 percent for agriculture and public administration, but the EU-SOR data covers a larger proportion of workers in education and health, and finance and professional services, and a smaller proportion of workers in the trade industry. Differences by occupation are below 1 percent for technicians, clerical support workers, and craft workers, but the EU-SOR data includes a larger proportion of managers and professionals, and a smaller proportion of service and sales workers, skilled agricultural workers, plant and machine operators, and workers in elementary occupations.

We repeat the same exercise in relation to earnings. Respondents in our survey are asked to provide an estimate of their net monthly earnings from their main paid job (converted to euros at the current exchange rate where necessary) and the number of hours of work in a typical week. The number of hours is recorded as less than 15 hours per week, then in 5-hour intervals up to 45 , with the last category corresponding to more than 45 hours. We compute the hourly net wage by dividing the reported wage by the estimated number of hours worked in a month (4.35*the midpoint of each category of weekly hours worked). In Table 1(column 1), the mean annual net wage is computed for a hypothetical full time worker working 40 hours per week 
and 52 weeks per year. The corresponding figure from Eurostat (column 2) is computed starting from gross wages and applying the average income tax for a single worker with average taxable income. The difference between the two calculations is about 5 percent.

\section{Table 1 about here}

Finally, in our estimates, we employ the survey weights that were developed by TNS (the organisation responsible for the implementation of the survey) to compensate for variation in selection probabilities and non-response bias. ${ }^{\text {ii }}$

\section{Methodology}

We estimate cross sectional wage regressions of the general form

$$
Y_{i}=b_{0}+b_{1} \text { Licensed }_{i}+X_{i} b_{2}+u_{i}
$$

where $Y_{i}$ denotes the log hourly wage of worker $i$, the matrix $X_{i}$ includes gender, education, union membership, work experience, working status, country, occupation, and industry fixed effects. The coefficient $b_{1}$ measures the impact of the indicator variable Licensed, which measures whether worker $i$ is subject to occupational licensing.

This approach assumes that the impact of occupational regulation is uniform across occupations, and that regulation cannot affect the return to other individual characteristics (the vector $b_{2}$ ). This assumption is restrictive, since regulation may affect differently workers in different occupations. Moreover, it may induce changes in the coefficients of other variables such as education or work experience. A more general model allows for different coefficients $b_{1}$ and $b_{2}$ for licensed and unlicensed workers.

Individuals in the survey can be partitioned into two exclusive groups denoted by $g=L, N$. Individuals in group $L$ are individuals who need a license to do their job, while those in group $N$ do not. The coefficients from the group-specific wage regressions

$$
Y_{g i}=\beta_{g 0}+X_{g i} \beta_{g 1}+u_{g i}
$$

can be used to decompose the difference in average outcomes between group $L$ and group $N$, 


$$
\Delta=\bar{Y}_{L}-\bar{Y}_{N}
$$

into the part explained by differences in characteristics $X$ across the two groups $\left(\Delta_{X}\right)$, and the structural component $\left(\Delta_{S}\right)$ that is due to differences in the coefficients $\beta_{g 0}$ and $\beta_{g 1}$ across the two groups,

$$
\begin{gathered}
\Delta=\Delta_{X}+\Delta_{S} \\
\Delta_{X}=\left(\bar{X}_{L}-\bar{X}_{N}\right) \hat{\beta}_{N 1} \\
\Delta_{S}=\left(\hat{\beta}_{L 0}-\hat{\beta}_{N 0}\right)+\bar{X}_{L}\left(\hat{\beta}_{L 1}-\hat{\beta}_{N 1}\right) .
\end{gathered}
$$

Hence, we can estimate by OLS the wage regressions (2) and then decompose the overall change in wages into what is driven by $\mathrm{X}$, that is $\Delta_{X}$, and what is driven by having a license, $\Delta_{S}$ (Oaxaca 1973 and Blinder 1973). More generally, one can decompose the entire distribution of wages and study the impact of licensing on any quantile of the wage distribution (DiNardo, Fortin and Lemieux 1996).

Cross sectional wage regressions have the advantage of being representative of all occupations. However, they are based on the usual assumption that $E(u \mid X)=0$. Hence, they cannot account for unobserved characteristics that could be related to the selection into licensing occupations. Decomposition methods rely on the same assumption. They provide interesting descriptive results, which can be interpreted as causal only under this fairly strong assumption.

\section{The prevalence of occupational licensing}

The following two questions are used in the EU-SOR to classify workers into three groups: (i) licensed; (ii) certified (or accredited), and (iii) unregulated:

\footnotetext{
"In addition to this education, do you have a professional certification, licence or did you have to take an exam which is required to practice your occupation?"

Instructions to interviewees: "A professional certification or licence shows you are qualified to perform a specific job and may give you the right to enter a regulated profession or professional association.

Instructions to interviewers: "Only include certifications or licences obtained by the respondent as an individual. Examples include "licensed medical doctor" and "licensed taxi driver [...]".
} 
1. Yes

(39.65\%)

2. No-but currently in process of obtaining one

$(0.95 \%)$

3. No............ (59.21\%)

4. Don't know/No answer $(0.19 \%)$

To distinguish between licensing and certification, those who answer 1 or 2 to the above question were then asked:

"Without this professional certification, licence or exam would you be legally allowed to practice your occupation?"

Instructions to the interviewer: Refer to the respondent's specific occupation and personal circumstances. Refer to the current laws and regulations affecting the respondent's occupation (current main paid job).

1. Yes

2. No

3. Don't know/No answer $(2.26 \%)$

A worker is classified as 'licensed' if she answers (1) or (2) in the first question and (2) in the second. A worker is classified as 'certified' if she answers (1) or (2) in the first question and (1) or (3) in the second, and 'unregulated' otherwise.

To ensure the validity of the survey instrument we derived the key questions from the previously validated instrument used in the Westat survey in the US by Kleiner and Krueger (2013). Second, the questionnaire was subject to piloting in all EU28 member states and no issues were raised in relation to the questions on regulation status. Further, it is encouraging that the 'Don't know/No answer' responses are small, suggesting that respondents understood the questions. Finally, the proportion of missing values in the data is similar to that observed for other questions such as 'economic activity of the firm or organization' and 'occupation', again suggesting that the questions were well understood. 
We estimate that just under half (43\%) of the EU workforce is subject to some form of regulation. In particular, 22\% of workers are licensed (Table 2). The proportion of licensed workers in the EU is broadly comparable to the most recent US estimates where, depending on the data source, it ranges from 29\% (Kleiner and Krueger 2013) to 20\% (Gittleman et al. 2018), although the latter cannot distinguish between licensing and certification with confidence. It is also comparable to other dominant labour market institutions such as trade unionism for which the latest estimates show an average level of union membership across the EU (weighted by the numbers employed in the different member states) to be $23 \%$ (Fulton 2015). As a policy alternative to licensing, certification seems considerably more widespread in the EU (22\%) compared to Kleiner and Krueger's and Gittleman et al.'s (2018) estimates of 6\% and 8\% respectively. However, the former study only focuses on government certification and the later only on private certification, while our estimates include both government and private certification. Hence, these figures are not directly comparable.

\section{Table 2 about here}

\section{a. Who is licensed in the European Union?}

We proceed with analysing the distribution of licensed, certified and unregulated workers based on key demographic and employment characteristics (Table 3). We find that licensing is more prevalent amongst those aged 40 to 64 years, but we do not find any marked differences by gender. Our results further indicate that the incidence of licensing is higher amongst employees in the public sector (32\%) and the self-employed, and least common amongst those in private firms $(16 \%)$. This is partly expected as many occupations with high information asymmetries and potential to cause harm to others are found in the public sector (e.g. medical occupations, teachers etc.) and amongst the self-employed (which is usually correlated with the provision of personal services e.g. plumbers, lawyers etc.). This trend is further reflected in the distribution of licensing by industrial classification, where we find that licensing is most prevalent in health and public administration and least common in the hotel, restaurant and retail industries. With respect to occupational groups, the incidence of licensing is highest amongst plant and machine operators (35\%), professionals (26\%), and technicians and associated professionals (27\%). 
In the case of craft and related trades (20\%) it is possible that the data is capturing the legacy of the guilds, the institution that for many centuries provided the main route for entry to such occupations in Europe, and one that shares many similarities to occupational regulation (Ogilvie 2014; Rostam-Afschar 2014; Epstein 1998). Unsurprisingly, the lowest proportion of licensed workers is found amongst occupations where information asymmetries and negative externalities are expected to be lowest (i.e. elementary occupations), and in occupational groups such as managers that perhaps lack a strong enough professional identity to organise and lobby for licensing. Finally, we find certification to be most widespread amongst craft and related trades occupations, skilled occupations in agriculture, forestry and fishing, as well as technicians and associated professionals, while it is more common than licensing in managerial occupations and less common than licensing amongst plant and machine operators.

Turning to education, the survey asks respondents to report the highest level of educational attainment. ${ }^{\text {iii }}$ We find licensing to be common throughout the different levels of educational attainment. In particular, it is common among individuals with lower secondary education (24.7\%), post-secondary education (26.8\%), and advanced research qualification (24\%). Interestingly, we find no stark differences between licensing and certification on one hand, and educational attainment on the other. However, it is noteworthy that contrary to licensing and certification, a large proportion of unregulated workers are concentrated in the low education category $(71 \%)$. Finally, licensing is slightly more common among union members, most likely driven by the higher incidence of licensing in the public sector where unionisation rates are commonly high. Our results are broadly in line with the characteristics of licensed workers observed by Kleiner and Krueger (2013) in the US, who also find a higher proportion of licensed workers in the public sector, amongst union members, and in the service industry.

Table 3 about here.

The EU-SOR asks respondents to report the minimum level of education necessary to become licensed $^{\text {iv }}$, as well as, additional entry hurdles such as examinations and work experience. Of course the presence of barriers to entry in itself is neither a guarantee of high quality services nor a signal of occupational closure, since it is the level at which these requirements are set that is likely to determine such outcomes. Nevertheless, it is suggestive of the hurdles that 
individuals have to overcome to practice the occupation vis-à-vis their unregulated counterparts. To gauge the barriers to entry associated with working in a licensed occupation, we provide estimates of the proportion of individuals that report being subject to such requirements (Table 4). We find passing an exam to be as widespread in the EU (affecting around $86 \%$ of licensed individuals) as it is in the US (affecting $85 \%$ according to Kleiner and Krueger). While for the majority work experience is not required (52\%), over a quarter require work experience of more than two years. With regards to education, either lower secondary, upper secondary or university qualifications are required for about three quarters of those licensed, although the proportion of those requiring no educational credentials is not insignificant (19\%). Interestingly, the requirement for a university degree is not as common in the EU as it is in the US ( $25 \%$ and $43 \%$ respectively). Overall, we find the restrictiveness of entry to licensed occupations in the EU to be comparable to that in the US in terms of the forms it takes, but not necessarily with respect to the proportion of licensed workers affected by them.

Table 4 about here.

Our data further provides us with information about the distribution of licensed workers across different member states (Table 5). Overall, the proportion of licensed workers ranges between $14 \%$ and $33 \%$ (Column 1). We find the largest proportion of licensed individuals in Germany $(33 \%)$, Croatia (31\%), Ireland (29\%) (with Slovakia, Hungary and the Netherlands following closely), and the smallest proportion in Sweden (15\%), Latvia (15\%), and Denmark (14\%). With the exception of Ireland, the high incidence of licensing in these countries could be indicative of the impact that institutions associated with the Habsburg Empire have had on the organisation of economic activities (see for example Becker et al. 2015). We further compare these data on individual attainment to the number of regulated professions in the EU Database of Regulated Occupations (Column 3). ${ }^{\mathrm{v}}$ Interestingly, we do not find a statistically significant correlation between the proportion of individuals subject to licensing and the number of licensed occupations in each member state $(r=.13, \mathrm{p}=\mathrm{n} . \mathrm{s}$.). For example, whilst the incidence of licensing within a member state might initially appear low compared to others (as measured by the number of occupations subject to licensing), the actual prevalence of licensing can be 
substantial if employment in these categories is disproportionately large. We depict the geographical variability of the proportion of licensed workers (Figure 1). Licensing is most prevalent in some Central and Eastern European countries, but there is no clear difference between North and South. Countries with high proportion of licensing seem to be located along a diagonal from North-West to South-East.

\section{Table 5 about here}

Figure 1 about here

\section{The Wage effects of Occupational Licensing}

To examine whether licensing is associated with higher pay, we present estimates of log wage regressions using individual level data (Table 6). In addition to the standard human capital controls, industry and detailed occupational controls, country fixed effects are also included in the models. Even including a rich set of controls, variability in individual level licensing status exists because of country-occupation specific licensing regulations. In fact, the same occupational code might include different licensed professions in each country, each with its own admission rules and requirements. Such differences generate heterogeneity across country-occupation cells and at the individual level, as workers with the same level of education, experience, etc. might be subject to different licensing regulations depending on their specific job in each country. Clearly, moving from left to right in Table 6, we progressively control for exogenous variables potentially affecting wages and exploit variability in licensing status across workers with more similar characteristics.

In our most basic specification, the mean wage of licensed workers is about 9.7 log points higher than that of unregulated workers. The coefficient of licensing then significantly drops as controls are progressively included, suggesting that a large portion of the premium is coming from educational endowments and other labour market characteristics, rather than licensing per se. In our more elaborate specifications, we find that having a licence is associated with approximately $4 \%$ higher hourly wages $(p<0.01)$. Such an effect is considerably lower in magnitude than the $18 \%$ licensing wage premium found by Kleiner and Krueger (2013) and 
closer to the more recent estimates of $10 \%$ by Kleiner and Vorotnikov (2018) and 7\% by Gittleman and Kleiner (2016).

\section{Table 6 about here}

\subsection{Signalling or entry restrictions?}

What is the mechanism that generates the observed wage gap between licensed and unlicensed workers? Occupational licensing may affect wages by improving human capital and providing a credible signal to consumers. However, it may also increase wages by restricting labour supply. In our data, we can observe a set of workers who report to hold a certification (on top of their educational achievements). This certification provides a signal of additional human capital, without necessarily being associated with a restriction in labour supply, as it is not a legal requirement. Due to the restrictiveness of licensing, in a wage regression we expect the coefficient of the indicator variable for licensed workers to be larger than that of certified workers. The difference between the two provides a measure of the impact of the legally enforced entry restrictions in increasing the wages of licensed workers.

The results from the wage regressions are shown in Table 7. We use the same specifications as in Table 6, but add an indicator variable for certification status. Interestingly, as with licensing, we find that certification has a positive and significant effect on wages. This is consistent with certification being associated with higher skills and having some signalling value in the labour market. However, in general, certification is associated with a smaller premium than licensing. In column 6 , this difference is about two percentage points $(0.0347, p<0.05$ for certification and $0.0519, p<0.01$ for licensing). Further, the difference between the coefficients of the 'licensed' and 'certified' dummies captures the impact of the legal requirement to hold a license, which is the main difference between certification and licensing. In fact, both licensing and certification provide a signal of worker quality. However, licensing also restricts entry into specific labor markets to licensed workers and it is therefore associated with a higher wage. Overall, the wage gap between licensed and unregulated workers is 5.19log points, of which one third can be attributed to entry restrictions and two thirds to signalling (although we note that the standard error of the difference between the two coefficients is large). 


\section{Table 7 about here}

In the analysis that follows, we disaggregate the wage effects of licensing and certification by occupation. This enables us to conduct within-occupation comparisons of those with licenses and certificates on one hand, and those without at major occupation level (1-digit). The first column in Table 8 includes interactions of the indicator variable for licensed workers with indicator variables for occupational groups. The second specification (column 2) includes the indicator variable for certification, while the third column includes interactions of the certification dummy with an indicator variable for each occupation. Overall, we find that licensing is having a differential effect by occupation. In column 1, the effect is of highest magnitude for craft and related trades occupations (16 log points) as well as elementary occupations (13 log points), service and sales workers (7 log points), and professionals (4 log points). This heterogeneity is not much affected in column 2. Finally, in column 3, the difference between the coefficients of 'licensed' and 'certified' are very heterogeneous across occupations. This difference is particularly large and statistically significant for craft and related trades workers as well as elementary occupations. Managerial occupations are typically unregulated and the few licensed workers in this category tend to have lower wages than certified workers.

\section{Table 8 about here}

\subsection{Occupational licensing and the return to education}

In line with the literature on returns to education (Becker 1993), we have shown that even after controlling for a large number of covariates in our wage regressions, the difference in wages due to education remains large. Yet, an unexplored line of enquiry in the empirical literature is the effect of occupational regulation on returns to education and in particular, how this varies between licensed, certified and unregulated workers. We address this by estimating wage regressions similar to our previous models allowing for group-specific returns to education. We split workers into three groups: elementary and lower secondary education, upper secondary and tertiary (non-college) education, and college or higher. In Table 9 and Figure 2, 
we report the results we obtain when we interact the 'licensing' and 'certification' indicator variables with indicator variables for different levels of educational achievement. For unregulated workers, the average wage grows with education, particularly for those with college education. For licensed workers, we obtain different results. While those with elementary education earn significantly more than unregulated workers, the wage growth for licensed workers with upper-secondary education is zero. Hence, licensing seems to decrease the returns to secondary education relative to unregulated workers.

The wages of workers with a college degree are significantly higher to those of workers with a secondary education for unregulated, certified, and licensed workers. However, wages of licensed workers with college education are significantly higher to those of similarly educated unregulated workers (the difference is $0.06, \mathrm{p}$-value 0.01 ). In comparison with unregulated workers, licensing flattens the returns to education for low levels of education, while it increases them for university qualifications. Estimates for certified workers show a pattern that is between that of unregulated and licensed workers. However, standard errors are large, and differences with respect to estimates for licensed workers are not statistically significant. Hence, we cannot precisely separate the impact of licensing and certification on the returns to education.

\section{Table 9 about here}

Figure 2 about here

\subsection{Oaxaca-Blinder decomposition}

The heterogeneity in wage premiums across occupations suggests that the linear model (1) may not capture some of the heterogeneous effects of licensing regulations. In fact, our results so far have highlighted the importance of heterogeneity in the licensing wage gap across occupations and educational groups. We now turn to the Oaxaca-Blinder decomposition, which does not constrain the effect of licensing to be constant for all workers, or even for workers within the same occupation or educational group.

The estimated coefficients of model (2) on the two groups (licensed and non-licensed) are reported in Table 10, together with the mean values of each variable. The table illustrates how licensing distorts the relative wage of different occupational groups. Licensed professionals earn on average 7.2 percent more than licensed managers, licensed craft workers 3.6 percent less, and licensed workers in elementary occupations 19.4 percent less. The table shows a very 
different pattern of relative wages for non-licensed workers. Non-licensed professionals earn 5.8 percent less than non-licensed managers, non-licensed craft workers earn 31.4 percent less, and non-licensed workers in elementary occupations 42.8 percent less. The occupations with the largest differences between the two figures are 'Professionals', 'Craft and related trades', 'Service and sales workers' and 'Elementary occupations'. These differences are consistent with the idea that licensing confers a wage premium that is particularly large for some occupations.

Table 11 describes the results of the decomposition in equation (4) based on the estimated coefficients. The overall difference in log wages between licensed and non-licensed workers (about 9 percent) can be decomposed into the part that is due to characteristics of the workers (composition effects) and that due to differences in regression coefficients (wage structure effect). The wage structure effect can be interpreted as a generalized version of the wage premium discussed in previous paragraphs. The composition effect accounts for $62 \%$ of the overall difference. Differences in occupation, age, and work experience are important determinants of the composition effect. The wage structure effect, due to differences in the estimated coefficients, accounts for about $38 \%$ of the overall effect. Differences in the coefficients of union membership, age, and occupation dummies are the most important contributors to the wage structure effect.

\section{Table 10 about here}

Table 11 about here

\section{Occupational Licensing and Wage Dispersion}

Our final analysis concerns the effect of licensing on the entire wage distribution, which we examine using the DiNardo, Fortin and Lemieux (1996) semiparametric decomposition method (DFL). In Figure 2, we depict the distribution of log hourly wages in the EU for licensed and non-licensed workers. We then decompose the difference between these two distributions into the composition effect and the wage structure effect. In Figure 3, we show the distribution for licensed workers and the estimated counterfactual density that would be obtained if these workers had the same characteristics as their non-licensed counterparts. The composition effect 
is equal to the difference between the two distributions. Finally, in Figure 4, we report the wage distribution of non-licensed workers and the same counterfactual density. The difference between these two distributions corresponds to the impact of licensing, holding constant the characteristics of workers. This is the semiparametric version of the wage structure effect introduced in equation (4).

Figure 3 about here

Figure 4 about here

Figure 5 about here

The results of the DFL decomposition can be used to compute statistics from the three distributions. In Table 12, we report the standard deviation, the variance, and the distances between selected quantiles. Differences in these statistics provide estimates of the composition and wage structure effects. The wage structure effect of licensing implies a significant increase in wage inequality as measured by the standard deviation of log hourly wages ( $2.8 \log$ points). The distance between the $99^{\text {th }}$ and the $1^{\text {st }}$, the $95^{\text {th }}$ and the $5^{\text {th }}$, the $90^{\text {th }}$ and the $10^{\text {th }}$ percentiles is also increased by licensing. Columns 6 and 7 show that the wage structure effect leads to an increase in the dispersion of wages in both tails of the distribution. In line with previous results on mean wages, we find that the median wage is increased by the wage structure effect (column 8). Our results generally support those of similar US studies using different sets of data and different methodologies (e.g. Gittleman and Kleiner 2016; Kleiner and Vorotnikov 2018).

\section{Table 12 about here}

\section{Conclusions}

We present the first ever estimates of the prevalence and wage effects of occupational regulation in the EU. We find that licensing affects about 22 percent of workers in the EU, albeit with significant variability across member states and occupations, leading us to conclude 
that it is an important labour market institution in this context. We further show that in line with our theoretical predictions, it has an effect on wages. In particular, licensing is associated with an aggregate wage premium of about $4 \%$ after accounting for observable characteristics of the workers, country and occupation fixed effects. This figure is somewhat lower than current US estimates. Overall, our analysis attributes approximately one third of the licensing wage gap to entry restrictions (associated with the monopoly effect of licensing), and the remaining to signalling.

We further present the first systematic analysis of its heterogeneous effect by occupation and by level of educational attainment. With regards to the former, licensing distorts wages differentially by occupation, possibly indicative of the varying degree to which occupations can extract monopoly rents in the market. Similarly, licensing compresses the returns to education for low educated individuals but increases the growth in the return to education for those with university degrees and above. Moreover, licensing disproportionately benefits those at the top of the income distribution, increasing the dispersion of wages. As such, occupational licensing differs from unionization, which is known to reduce wage dispersion. Overall, future studies of occupational licensing will benefit by incorporating these heterogeneous effects into their analyses.

We also account for the possible effect of certifications that are not legally required to practice an occupation but may signal the existence of labour market skills not fully captured by conventional education. Our estimates are in line with the most recent findings in the US in that certification is also associated with a wage premium, but not of comparable magnitude to that of licensing. In that sense, certification is perhaps a useful policy alternative in that it improves the skills of practitioners, signals the existence of a minimum standard to consumers while allowing them to choose whether they are willing to pay the premium associated with using a certified practitioner.

A key novelty of our approach is our ability to estimate the incidence of regulation based on self-reported measures of regulation status rather than rely on inferences from occupational classifications. However, the nature of our data does not allow us to rule out the possibility of selection bias on unobservables hence we interpret the results as descriptive rather than casual evidence. Nevertheless, the limitations of the current study open up fruitful avenues for future research, particularly in the form of devising ways to explore exogenous variation in the licensing status. 


\section{References}

Becker, Gary (1993), Human Capital: A Theoretical and Empirical Analysis, with Special Reference to Education, 3rd edition, The University of Chicago Press, Chicago, IL.

Becker, S. O., Boeckh, K., Hainz, C and Woessmann, L. (2015). The empire is dead, long live the empire! Long-run persistence of trust and corruption in the bureaucracy. The Economic Journal, 126(590), 40-74.

Blinder, A. (1973) Wage Discrimination: Reduced Form and Structural Estimates, The Journal of Human Resources, 8(4) 436-455.

Curtin, R., Presser, S and Singer, E. (2005). Changes in telephone survey nonresponse over the past quarter century. Public Opinion Quarterly, 69(1), 87-98.

DiNardo, J., Fortin, N.M. and Lemieux, T (1996). "Labor Market Institutions and the Distribution of Wages, 1973-1992: A Semiparametric Approach”. Econometrica 64 (5), 1001-44.

Epstein, S. R. (1998) Craft guilds, apprenticeship, and technological change in preindustrial Europe. The Journal of Economic History, 58(3): 684-713.

Forth, J., Bryson, A., Humphris, A., Kleiner, M. and Koumenta, M. (2011) A Review of Occupational Regulation and its Impact, UK Commission for Employment and Skills, London

Fulton, L. (2015) Worker representation in Europe, available from https://www.workerparticipation.eu/National-Industrial-Relations/Across-Europe/Trade-Unions

Freeman, R. B. (1991). How much has de-unionisation contributed to the rise in male earnings inequality? (No. w3826). National Bureau of Economic Research. 
Gittleman, M., Klee, M. A and Kleiner, M. (2018). Analyzing the labor market outcomes of occupational licensing. Industrial Relations: A Journal of Economy and Society, $57(1), 57-100$.

Gittleman, M., \& Kleiner, M. M. (2016). Wage effects of unionization and occupational licensing coverage in the United States. ILR Review, 69(1), 142-172.

Kleiner, M. (2000). Occupational licensing. The Journal of Economic Perspectives, 14(4), 189202.

Kleiner, M. and Krueger A. (2013) 'Analysing the Extent and Influence of Occupational Licensing on the Labor Market, Journal of Labor Economics, 31, (2), ), S173-S202.

Kleiner, M. M., and Vorotnikov, E. (2017). Analyzing occupational licensing among the states. Journal of Regulatory Economics, 52(2), 132-158.

Koumenta, M., Humphris, A., Kleiner, M. and Pagliero, M. (2014). Occupational Regulation in the UK and EU: Prevalence and Labour Market Impact, Department for Business, Innovation and Skills, London.

Maurizi, A. (1974). Occupational licensing and the public interest. Journal of Political Economy, 82(2, Part 1), 399-413.

Oaxaca, R. (1973), Male-Female Wage Differentials in Urban Labor Markets, International Economic Review, 14( 3), 693-709.

Ogilvie, S. (2014). The economics of guilds. Journal of Economic Perspectives, 28(4), 169-92.

Pagliero, M. (2013) The Impact of Potential Labour Supply on Licensing Exam Difficulty, Labour Economics, 25, 141-152.

Pagliero, M. (2011). What is the objective of professional licensing? Evidence from the US market for lawyers. International journal of Industrial organization, 29(4), 473-483.

Pagliero, M. (2010). Licensing exam difficulty and entry salaries in the US market for lawyers. British Journal of Industrial Relations, 48 (4), 726-739.

Rostam-Afschar, D. (2014). Entry regulation and entrepreneurship: a natural experiment in German craftsmanship. Empirical Economics, 47(3), 1067-1101. 
Shapiro, C. (1986) Investment, Moral Hazard and Occupational Licensing. Review of Economic Studies, 53, 843-62.

Timmons, E. and Thornton, R. (2010). The Licensing of Barbers in the US. British Journal of Industrial Relations, 48(4), 740-757 


\section{TABLES}

Table 1. Comparison of characteristics of EU workers in the Survey of Occupational Licensing and in the Eurostat Labour Force Survey (civilian employment)

by educational attainment:

Less than primary, primary and

lower secondary education (levels

$0-2)$

Upper secondary and post-

secondary non-tertiary education

(levels 3 and 4)

Tertiary education (levels 5-8)

Male

From 15 to 39 years

From 40 to 64 years

65 years or over

\section{Employees}

Self-employed persons with

employees (employers)

Self-employed persons without employees (own-account workers)
0.169

0.183

$-0.014$

0.439

0.481

$-0.042$

0.392

0.542

0.436

0.543

0.021

0.851

0.043

0.105

0.332

0.060

0.540

0.002

0.427

0.550

0.009

$-0.007$

0.023

$-0.003$

0.850

0.001

0.042

0.001

$-0.002$ 


\begin{tabular}{|c|c|c|c|c|}
\hline \multirow[t]{6}{*}{ by industry } & Agriculture & 0.037 & 0.046 & -0.009 \\
\hline & Manufacturing and construction & 0.225 & 0.240 & -0.015 \\
\hline & Education and health & 0.225 & 0.185 & 0.040 \\
\hline & Trade & 0.211 & 0.267 & -0.056 \\
\hline & $\begin{array}{l}\text { Finance and professional services } \\
\text { and other services }\end{array}$ & 0.225 & 0.194 & 0.031 \\
\hline & Public administration & 0.078 & 0.069 & 0.009 \\
\hline \multirow[t]{9}{*}{ by occupation } & Managers & 0.100 & 0.060 & 0.040 \\
\hline & Professionals & 0.276 & 0.188 & 0.088 \\
\hline & $\begin{array}{l}\text { Technicians and associate } \\
\text { professionals }\end{array}$ & 0.158 & 0.158 & 0.000 \\
\hline & Clerical support workers & 0.096 & 0.097 & -0.001 \\
\hline & Service and sales workers & 0.140 & 0.167 & -0.027 \\
\hline & $\begin{array}{l}\text { Skilled agricultural, forestry and } \\
\text { fishery }\end{array}$ & 0.016 & 0.039 & -0.022 \\
\hline & Crafts and related workers & 0.107 & 0.116 & -0.009 \\
\hline & $\begin{array}{l}\text { Plant and machine operators and } \\
\text { assemblers }\end{array}$ & 0.051 & 0.074 & -0.022 \\
\hline & Elementary occupations & 0.055 & 0.092 & -0.037 \\
\hline Mean Net Earnings & & 22,037 & 23,142 & $-1,105$ \\
\hline
\end{tabular}


Table 2. The prevalence of occupational licensing in the European Union.

\begin{tabular}{ccc}
\hline & Proportion & $\begin{array}{c}\text { Std. } \\
\text { Error }\end{array}$ \\
\hline Licensed & 0.219 & 0.0048 \\
Certified & 0.217 & 0.0049 \\
Unregulated & 0.564 & 0.0058 \\
\hline
\end{tabular}

Note: the table reports the proportion of licensed, certified, and unregulated workers. The proportions of licensed and certified workers include individuals in the process of obtaining their qualification. The proportions of these individuals are 0.004 and 0.009 respectively. 
Table 3. Proportion of licensed, certified, and unregulated workers by worker characteristics.

\begin{tabular}{|c|c|c|c|}
\hline & Licensed & Certified & Unregulated \\
\hline \multicolumn{4}{|l|}{ Gender } \\
\hline Female & 0.218 & 0.202 & 0.580 \\
\hline Male & 0.220 & 0.230 & 0.551 \\
\hline \multicolumn{4}{|l|}{ Age } \\
\hline From 15 to 39 years & 0.195 & 0.205 & 0.600 \\
\hline From 40 to 64 years & 0.239 & 0.224 & 0.537 \\
\hline 65 years or over & 0.200 & 0.286 & 0.514 \\
\hline \multicolumn{4}{|l|}{ Employment status } \\
\hline Employee in a private firm & 0.159 & 0.217 & 0.624 \\
\hline $\begin{array}{l}\text { Employee in public/non-profit } \\
\text { sector }\end{array}$ & 0.322 & 0.217 & 0.462 \\
\hline Self-employed with employees & 0.241 & 0.213 & 0.545 \\
\hline Self-employed without employees & 0.220 & 0.217 & 0.563 \\
\hline \multicolumn{4}{|l|}{ Occupation } \\
\hline Managers & 0.127 & 0.210 & 0.663 \\
\hline Professionals & 0.263 & 0.229 & 0.508 \\
\hline $\begin{array}{l}\text { Technicians and associate } \\
\text { professionals }\end{array}$ & 0.271 & 0.236 & 0.493 \\
\hline Clerical support workers & 0.145 & 0.169 & 0.686 \\
\hline Service and sales workers & 0.218 & 0.214 & 0.568 \\
\hline $\begin{array}{l}\text { Skilled agricultural, forestry and } \\
\text { fishing }\end{array}$ & 0.160 & 0.239 & 0.602 \\
\hline Craft and related trades workers & 0.199 & 0.268 & 0.533 \\
\hline $\begin{array}{l}\text { Plant and machine operators and } \\
\text { assemblers }\end{array}$ & 0.349 & 0.176 & 0.475 \\
\hline Elementary occupations & 0.105 & 0.153 & 0.742 \\
\hline \multicolumn{4}{|l|}{ Industry } \\
\hline Agriculture $(A)$ & 0.141 & 0.211 & 0.649 \\
\hline Manufacturing of products $(B, C)$ & 0.128 & 0.228 & 0.644 \\
\hline Construction or energy $(D, E, F)$ & 0.213 & 0.268 & 0.519 \\
\hline Wholesale or retail trade & 0.106 & 0.199 & 0.695 \\
\hline Hotels and restaurants (I) & 0.096 & 0.206 & 0.698 \\
\hline Transportation and communication & 0.267 & 0.212 & 0.520 \\
\hline Finance, real estate $(K, L)$ & 0.242 & 0.217 & 0.541 \\
\hline Public administration (O) & 0.349 & 0.198 & 0.453 \\
\hline Education (P) & 0.271 & 0.226 & 0.503 \\
\hline Health and social work (Q) & 0.367 & 0.196 & 0.438 \\
\hline
\end{tabular}


Professional services

0.209

0.219

0.571

Cultural activities

0.148

0.210

0.641

Education

Primary

0.123

0.165

0.712

Lower secondary

0.247

0.286

0.467

Upper secondary

0.209

0.208

0.583

Post-secondary

0.268

0.211

0.521

University

(undergraduate/postgraduate)

0.215

0.204

0.580

$\mathrm{PhD} /$ advanced search qualification

0.240

0.163

0.597

Trade union membership

$\begin{array}{llll}\text { Yes } & 0.280 & 0.224 & 0.496 \\ \text { No } & 0.201 & 0.214 & 0.585\end{array}$

Source: EU Survey of Regulated Occupations. Civilian employed population age 15 or older.

Note: the proportion of licensed and certified workers includes individuals in the process of obtaining their qualification 
Table 4. Requirements to obtain a license.

Proportion of Licensed Workers

subject to the specific requirement Std. error

Specific requirement:

Entry examination

0.864

0.009

\section{Educational requirement:}

No requirement

0.191

0.010

Primary education

0.024

0.003

Lower secondary

0.209

0.011

Upper secondary

0.279

0.011

Post-secondary education

0.046

0.006

University

0.247

0.011

PHD/ adv. research

0.005

0.001

\section{Experience requirement:}

No work experience is/was required

0.524

0.013

Up to a year

0.094

0.006

More than 1 year up to 2 years

0.094

0.007

Longer than 2 years

0.288

0.012

Source: EU Survey of Regulated Occupations. Civilian employed population age 15 or older.

Note: the proportion of licensed and certified workers includes individuals in the process of obtaining their qualification. 
Table 5. The proportion of licensed workers by country.

$\begin{array}{lccc} & \begin{array}{c}\text { Proportion of } \\ \text { Licensed Workers }\end{array} & \begin{array}{c}\text { Number of } \\ \text { Licensed }\end{array} \\ \text { Occupations }\end{array}$

a Source: EU Survey of Regulated Occupations. Civilian employed population age 15 or older.

bSource: EU Database of Regulated Occupations.

Note: the proportion of licensed and certified workers includes individuals in the process of obtaining their qualification. 
Table 6. Coefficients from log wage regressions.

(1)

(2)

(3)

(4)

(5)

(6)

Licensed

$0.0967 * * *$

$0.0531^{* * *}$

$0.0453 * * *$

(0.0222)

(0.0149)

(0.0145)

$0.0415^{* * *}$

$0.0365 * *$

$0.0402 * * *$

Union

$0.0381 * * \quad 0.00567$

$(0.0144)$

(0.0145)

(0.0148)

(0.0159)

(0.0157)

0.0149

0.0123

0.0119

$0.174^{* * *} \quad 0.173^{* * *}$

$(0.0161)$

$(0.0157)$

(0.0156)

(0.0129)

(0.0129)

$0.165^{* * *}$

$0.148 * * *$

$0.149 * * *$

$0.0104 * * *$

(0.0135)

(0.0135)

(0.0139)

Age

$(0.000682)$

$0.00668^{* * *}$

$0.00636 * * *$

$0.00627 * * *$

$0.00632^{* * *}$

Lower secondary education (usually age 11-15)

Upper secondary education (usually age 16-19)

$\begin{array}{ccccc}0.141^{* * *} & 0.133^{* * *} & 0.0926^{* *} & 0.0841^{*} & 0.0864^{*} \\ (0.0462) & (0.0466) & (0.0433) & (0.0438) & (0.0443) \\ & & & & \\ 0.249^{* * *} & 0.235^{* * *} & 0.160^{* * *} & 0.151^{* * *} & 0.155^{* * *} \\ (0.0424) & (0.0430) & (0.0406) & (0.0409) & (0.0413) \\ & & & & \\ 0.313^{* * *} & 0.297^{* * *} & 0.182^{* * *} & 0.174^{* * *} & 0.173^{* * *} \\ (0.0490) & (0.0491) & (0.0471) & (0.0473) & (0.0481) \\ & & & & \\ 0.578^{* * *} & 0.569^{* * *} & 0.378^{* * *} & 0.358^{* * *} & 0.354^{* * *} \\ (0.0429) & (0.0435) & (0.0426) & (0.0429) & (0.0433) \\ 0.800^{* * *} & 0.810^{* * *} & 0.583^{* * *} & 0.577^{* * *} & 0.570^{* * *} \\ (0.0537) & (0.0550) & (0.0544) & (0.0541) & (0.0542) \\ & 0.0179 * * * & 0.0151^{* * *} & 0.0145^{* * *} & 0.0141^{* * *} \\ & (0.00240) & (0.00233) & (0.00231) & (0.00225) \\ & -0.313^{* * *} & -0.270^{* * *} & -0.260^{* * *} & -0.253^{* * *}\end{array}$




\begin{tabular}{|c|c|c|c|c|c|c|}
\hline & & & $(0.0729)$ & $(0.0711)$ & $(0.0702)$ & $(0.0682)$ \\
\hline \multicolumn{3}{|l|}{ Employee in public sector or non-profit } & & -0.000500 & 0.0253 & 0.0255 \\
\hline \multicolumn{3}{|l|}{ Self-employed with employees } & & $0.182 * * *$ & $0.194^{* * *}$ & $0.202 * * *$ \\
\hline \multirow{2}{*}{\multicolumn{3}{|c|}{ Self-employed without employees }} & & $-0.0653 *$ & -0.0464 & -0.0434 \\
\hline & & & & $(0.0392)$ & $(0.0385)$ & $(0.0362)$ \\
\hline Country f.e? & & yes & yes & yes & yes & yes \\
\hline Detailed occupation controls? & & & & & & yes \\
\hline Observations & 16,067 & 16,027 & 15,952 & 15,952 & 15,952 & 15,796 \\
\hline R-Squared & 0.003 & 0.668 & 0.675 & 0.699 & 0.706 & 0.710 \\
\hline
\end{tabular}

Note: The dependent variable is the log of hourly wage. Omitted indicator variables: Primary education, Employee in private firm or business. Individuals in the process of obtaining a license are classified as unregulated.

Robust standard errors in parentheses. ${ }^{* * *} \mathrm{p}<0.01,{ }^{* *} \mathrm{p}<0.05,{ }^{*} \mathrm{p}<0$. 
Table 7. Coefficients from log wage regressions (licensing and certification).

\begin{tabular}{|c|c|c|c|c|c|c|}
\hline & (1) & $(2)$ & (3) & (4) & (5) & (6) \\
\hline licensed & $\begin{array}{c}0.116^{* * *} \\
(0.0230)\end{array}$ & $\begin{array}{c}0.0673 * * * \\
(0.0154)\end{array}$ & $\begin{array}{c}0.0596 * * * \\
(0.0152)\end{array}$ & $\begin{array}{c}0.0533 * * * \\
(0.0152)\end{array}$ & $\begin{array}{c}0.0481 * * * \\
(0.0152)\end{array}$ & $\begin{array}{c}0.0519 * * * \\
(0.0154)\end{array}$ \\
\hline certified & $\begin{array}{c}0.0734 * * * \\
(0.0256)\end{array}$ & $\begin{array}{c}0.0476 * * * \\
(0.0175)\end{array}$ & $\begin{array}{c}0.0478 * * * \\
(0.0173)\end{array}$ & $\begin{array}{c}0.0374 * * \\
(0.0166)\end{array}$ & $\begin{array}{c}0.0359 * * \\
(0.0163)\end{array}$ & $\begin{array}{c}0.0347^{* *} \\
(0.0161)\end{array}$ \\
\hline union & & $\begin{array}{c}0.0360 * * \\
(0.0158)\end{array}$ & $\begin{array}{l}0.00356 \\
(0.0156)\end{array}$ & $\begin{array}{c}0.0138 \\
(0.0160)\end{array}$ & $\begin{array}{c}0.0112 \\
(0.0156)\end{array}$ & $\begin{array}{c}0.0108 \\
(0.0156)\end{array}$ \\
\hline male & & $\begin{array}{c}0.172 * * * \\
(0.0129)\end{array}$ & $\begin{array}{c}0.172 * * * \\
(0.0129)\end{array}$ & $\begin{array}{c}0.164 * * * \\
(0.0136)\end{array}$ & $\begin{array}{c}0.147^{* * *} \\
(0.0135)\end{array}$ & $\begin{array}{c}0.148 * * * \\
(0.0139)\end{array}$ \\
\hline age & & $\begin{array}{l}0.0103 * * * \\
(0.000671)\end{array}$ & $\begin{array}{c}0.00654 * * * \\
(0.000783)\end{array}$ & $\begin{array}{c}0.00625^{* * *} \\
(0.000753)\end{array}$ & $\begin{array}{c}0.00617^{* * *} \\
(0.000728)\end{array}$ & $\begin{array}{c}0.00623 * * * \\
(0.000717)\end{array}$ \\
\hline Lower secondary education (usually age 11-15) & & $\begin{array}{l}0.138 * * * \\
(0.0462)\end{array}$ & $\begin{array}{l}0.130 * * * \\
(0.0466)\end{array}$ & $\begin{array}{c}0.0903 * * \\
(0.0432)\end{array}$ & $\begin{array}{l}0.0820 * \\
(0.0437)\end{array}$ & $\begin{array}{l}0.0848 * \\
(0.0443)\end{array}$ \\
\hline Upper secondary education (usually age 16-19) & & $\begin{array}{c}0.247 * * * \\
(0.0425)\end{array}$ & $\begin{array}{c}0.234 * * * \\
(0.0430)\end{array}$ & $\begin{array}{c}0.159 * * * \\
(0.0406)\end{array}$ & $\begin{array}{c}0.150 * * * \\
(0.0409)\end{array}$ & $\begin{array}{c}0.154 * * * \\
(0.0414)\end{array}$ \\
\hline Post-secondary education (not university) & & $\begin{array}{l}0.312 * * * \\
(0.0490)\end{array}$ & $\begin{array}{c}0.296 * * * \\
(0.0491)\end{array}$ & $\begin{array}{c}0.182 * * * \\
(0.0471)\end{array}$ & $\begin{array}{c}0.174 * * * \\
(0.0473)\end{array}$ & $\begin{array}{c}0.173 * * * \\
(0.0482)\end{array}$ \\
\hline University (undergraduate and post-graduate) & & $\begin{array}{c}0.577 * * * \\
(0.0430)\end{array}$ & $\begin{array}{c}0.568 * * * \\
(0.0435)\end{array}$ & $\begin{array}{c}0.378 * * * \\
(0.0426)\end{array}$ & $\begin{array}{c}0.359 * * * \\
(0.0430)\end{array}$ & $\begin{array}{c}0.355 * * * \\
(0.0434)\end{array}$ \\
\hline PHD/ advanced research qualification & & $\begin{array}{c}0.802 * * * \\
(0.0539)\end{array}$ & $\begin{array}{c}0.812^{* * *} \\
(0.0553)\end{array}$ & $\begin{array}{c}0.586 * * * \\
(0.0546)\end{array}$ & $\begin{array}{c}0.580 * * * \\
(0.0543)\end{array}$ & $\begin{array}{c}0.575 * * * \\
(0.0545)\end{array}$ \\
\hline Experience & & & $\begin{array}{c}0.0179 * * * \\
(0.00241)\end{array}$ & $\begin{array}{c}0.0151 * * * \\
(0.00234)\end{array}$ & $\begin{array}{c}0.0145 * * * \\
(0.00232)\end{array}$ & $\begin{array}{c}0.0141 * * * \\
(0.00225)\end{array}$ \\
\hline Experience $^{2} / 1,000$ & & & $\begin{array}{c}-0.311^{* * *} \\
(0.0734)\end{array}$ & $\begin{array}{c}-0.269 * * * \\
(0.0715)\end{array}$ & $\begin{array}{c}-0.259 * * * \\
(0.0705)\end{array}$ & $\begin{array}{c}-0.252 * * * \\
(0.0685)\end{array}$ \\
\hline
\end{tabular}




\begin{tabular}{|c|c|c|c|c|c|c|}
\hline \multirow[t]{2}{*}{ Employee in public sector or non-profit } & & & & -0.00256 & 0.0239 & 0.0243 \\
\hline & & & & (0.0139) & $(0.0190)$ & $(0.0186)$ \\
\hline \multirow[t]{2}{*}{ Self-employed with employees } & & & & $0.182 * * *$ & $0.194 * * *$ & $0.203^{* * *}$ \\
\hline & & & & $(0.0527)$ & $(0.0527)$ & $(0.0528)$ \\
\hline \multirow[t]{2}{*}{ Self-employed without employees } & & & & $-0.0663^{*}$ & -0.0470 & -0.0439 \\
\hline & & & & $(0.0392)$ & $(0.0385)$ & $(0.0362)$ \\
\hline Country f.e? & & yes & yes & yes & yes & yes \\
\hline Occupation controls? & & & & yes & yes & \\
\hline Industry controls? & & & & & yes & yes \\
\hline Detailed occupation controls? & & & & & & yes \\
\hline Observations & 16,067 & 16,027 & 15,952 & 15,952 & 15,952 & 15,796 \\
\hline R-squared & 0.004 & 0.668 & 0.676 & 0.699 & 0.706 & 0.711 \\
\hline Licensed - Certified & 0.0425 & 0.0197 & 0.0118 & 0.0159 & 0.0122 & 0.0172 \\
\hline s.e. & $(0.0297)$ & (0.0199) & (0.0194) & $(0.0186)$ & $(0.0187)$ & $(0.0188)$ \\
\hline
\end{tabular}

Note: The dependent variable is the log of hourly wage. Omitted indicator variables: Primary education, Employee in private firm or business. .Individuals in the process of obtaining a license or certification are classified as unregulated. Robust standard errors in parentheses $* * * p<0.01, * * p<0.05, * p<0.1$. 
Table 8. Coefficients from log wage regressions (licensing and certification) with interactions.

\begin{tabular}{|c|c|c|c|}
\hline & $(1)$ & $(2)$ & (3) \\
\hline \multirow[t]{2}{*}{ licensed $\mathrm{x}$ managers } & -0.0933 & -0.0842 & -0.0788 \\
\hline & $(0.0680)$ & $(0.0682)$ & $(0.0695)$ \\
\hline \multirow[t]{2}{*}{ licensed $x$ professionals } & $0.0446^{*}$ & $0.0561^{* *}$ & $0.0610 * *$ \\
\hline & $(0.0254)$ & $(0.0254)$ & $(0.0260)$ \\
\hline \multirow[t]{2}{*}{ licensed x Technicians and associate professionals } & -0.0031 & 0.0108 & 0.0118 \\
\hline & $(0.0314)$ & $(0.0323)$ & $(0.0348)$ \\
\hline \multirow[t]{2}{*}{ licensed x Clerical support workers } & 0.0423 & 0.0517 & 0.0536 \\
\hline & $(0.0495)$ & $(0.0496)$ & $(0.0502)$ \\
\hline \multirow[t]{2}{*}{ licensed $x$ Service and sales workers } & $0.0747^{* *}$ & $0.0868 * * *$ & $0.0852 * * *$ \\
\hline & $(0.0302)$ & $(0.0306)$ & $(0.0320)$ \\
\hline \multirow[t]{2}{*}{ licensed x Skilled agricultural } & 0.0144 & 0.0260 & 0.0190 \\
\hline & $(0.2436)$ & $(0.2445)$ & $(0.2407)$ \\
\hline \multirow[t]{2}{*}{ licensed $x$ Craft and related trades workers } & $0.1575 * * *$ & $0.1716 * * *$ & $0.1771^{* * *}$ \\
\hline & $(0.0383)$ & $(0.0388)$ & $(0.0409)$ \\
\hline \multirow[t]{2}{*}{ licensed $x$ Plant and machine operators } & -0.0560 & -0.0438 & -0.0657 \\
\hline & $(0.0538)$ & $(0.0540)$ & $(0.0561)$ \\
\hline \multirow[t]{2}{*}{ licensed x Elementary occupations } & 0.1292 & 0.1358 & 0.1076 \\
\hline & $(0.0831)$ & $(0.0829)$ & $(0.0842)$ \\
\hline \multirow[t]{2}{*}{ certified } & & $0.0369 * *$ & \\
\hline & & $(0.0164)$ & \\
\hline \multirow[t]{2}{*}{ certified $\mathrm{x}$ managers } & & & 0.0662 \\
\hline & & & $(0.0564)$ \\
\hline \multirow[t]{2}{*}{ certified $\mathrm{x}$ professionals } & & & 0.0530 \\
\hline & & & $(0.0358)$ \\
\hline \multirow[t]{2}{*}{ certified $\mathrm{x}$ Technicians and associate professionals } & & & 0.032273 \\
\hline & & & $(0.0349)$ \\
\hline certified x Clerical support workers & & & 0.0495 \\
\hline
\end{tabular}




\begin{tabular}{|c|c|c|}
\hline & & $(0.0481)$ \\
\hline \multirow[t]{2}{*}{ certified $x$ Service and sales workers } & & 0.0349 \\
\hline & & $(0.0462)$ \\
\hline \multirow[t]{2}{*}{ certified $x$ Skilled agricultural } & & 0.0155 \\
\hline & & $(0.2166)$ \\
\hline \multirow[t]{2}{*}{ certified $x$ Craft and related trades workers } & & 0.0547 \\
\hline & & $(0.0383)$ \\
\hline \multirow[t]{2}{*}{ certified $x$ Plant and machine operators } & & -0.0325 \\
\hline & & $(0.0436)$ \\
\hline \multirow[t]{2}{*}{ certified x Elementary occupations } & & $-0.1246^{*}$ \\
\hline & & $(0.0730)$ \\
\hline \multicolumn{3}{|l|}{ Difference between licensing and certification: } \\
\hline \multirow[t]{2}{*}{ Managers } & $-0.1211^{*}$ & $-0.1449 *$ \\
\hline & $(0.0692)$ & $(0.0804)$ \\
\hline \multirow[t]{2}{*}{ Professionals } & 0.0192 & 0.0080 \\
\hline & $(0.0283)$ & $(0.0379)$ \\
\hline \multirow[t]{2}{*}{ Technicians and associate professionals } & -0.0260 & -0.0304 \\
\hline & $(0.0328)$ & $(0.0367)$ \\
\hline \multirow[t]{2}{*}{ Clerical support workers } & 0.0148 & 0.0041 \\
\hline & $(0.0515)$ & (0.0639) \\
\hline \multirow[t]{2}{*}{ Service and sales workers } & 0.0500 & 0.0503 \\
\hline & $(0.0323)$ & $(0.0467)$ \\
\hline \multirow[t]{2}{*}{ Skilled agricultural } & -0.0109 & 0.0035 \\
\hline & $(0.2450)$ & $(0.3122)$ \\
\hline \multirow[t]{2}{*}{ Craft and related trades workers } & $0.1348^{* * *}$ & $0.1224^{* * *}$ \\
\hline & $(0.0398)$ & $(0.0453)$ \\
\hline \multirow{2}{*}{ Plant and machine operators } & -0.0806 & -0.0332 \\
\hline & -0.0552 & $(0.0602)$ \\
\hline Elementary occupations & 0.0990 & $0.2322 * *$ \\
\hline
\end{tabular}


$(0.0844)$

$-0.1012$

Note: The dependent variable is the log of hourly wage. The coefficients of education, occupation, industry, work status, gender, union indicators, age, experience, and experience squared are not reported. Individuals in the process of obtaining a license or certification are classified as unregulated. Robust standard errors in parentheses $* * * p<0.01, * * p<0.05, * p<0.1$ 
licensed

certified

$0.0703^{*}$

Licensed $x$ Upper secondary education and Post-secondary education (not university)

$(0.0372)$

Licensed x University education (and higher)

Certified $x$ Upper secondary education and Post-secondary education (not university)

Certified x University education (and higher)

(0.0436)

$-0.0391$

(0.0484)

Upper secondary education and Post-secondary education (not university)

University education (and higher)

Country f.e?

Occupation controls?

Industry controls?

Detailed occupation controls?

R-squared

Note: The dependent variable is the log of hourly wage. See Figure 1 for graphical representation. Omitted indicator variables: Primary and lower secondary education, Employee in private firm or business. The coefficients of occupation, industry, work status, gender, union indicators, age, experience, and experience 
squared are not reported. Individuals in the process of obtaining a license or certification are classified as

unregulated. Robust standard errors in parentheses ${ }^{* * *} p<0.01,{ }^{* *} p<0.05,{ }^{*} p<0.1$ 


\begin{tabular}{|c|c|c|c|c|c|c|}
\hline & $\begin{array}{c}\text { (1) } \\
\text { Licensed } \\
\text { Means }\end{array}$ & $\begin{array}{c}\text { (2) } \\
\text { Non- } \\
\text { licensed } \\
\text { Means }\end{array}$ & $\begin{array}{c}\text { (3) } \\
\text { Licensed } \\
\text { coeff. }\end{array}$ & $\begin{array}{c}\text { (4) } \\
\text { Licensed } \\
\text { s.e. }\end{array}$ & $\begin{array}{c}\text { (5) } \\
\text { Non- } \\
\text { licensed } \\
\text { coeff. }\end{array}$ & $\begin{array}{c}\text { (6) } \\
\text { Non-licensed } \\
\text { s.e. } \\
\end{array}$ \\
\hline union & 0.323 & 0.236 & -0.033 & 0.026 & 0.026 & 0.019 \\
\hline age & 43.531 & 41.512 & 0.003 & 0.001 & 0.007 & 0.001 \\
\hline Experience & 12.706 & 10.833 & 0.013 & 0.003 & 0.015 & 0.003 \\
\hline Experience ${ }^{2} / 1,000$ & 0.274 & 0.224 & -0.133 & 0.079 & -0.300 & 0.087 \\
\hline male & 0.562 & 0.534 & 0.120 & 0.025 & 0.152 & 0.015 \\
\hline \multicolumn{7}{|c|}{ Education (primary education omitted): } \\
\hline Lower secondary education (usually age 11-15) & 0.152 & 0.140 & 0.048 & 0.067 & 0.072 & 0.048 \\
\hline Upper secondary education (usually age 16-19) & 0.354 & 0.365 & 0.096 & 0.062 & 0.149 & 0.045 \\
\hline Post-secondary education (not university) & 0.076 & 0.064 & 0.086 & 0.090 & 0.186 & 0.051 \\
\hline University (undergraduate and post-graduate) & 0.382 & 0.377 & 0.342 & 0.069 & 0.343 & 0.047 \\
\hline PHD/ advanced research qualification & 0.023 & 0.022 & 0.536 & 0.090 & 0.569 & 0.061 \\
\hline \multicolumn{7}{|c|}{ Occupation (managers omitted): } \\
\hline Professionals & 0.320 & 0.260 & 0.072 & 0.064 & -0.058 & 0.028 \\
\hline Technicians and associate professionals & 0.190 & 0.145 & -0.031 & 0.067 & -0.142 & 0.030 \\
\hline Clerical support workers & 0.061 & 0.109 & -0.113 & 0.078 & -0.239 & 0.030 \\
\hline Service and sales workers & 0.149 & 0.142 & -0.145 & 0.066 & -0.336 & 0.031 \\
\hline Skilled agricultural & 0.009 & 0.014 & -0.334 & 0.230 & -0.383 & 0.085 \\
\hline Craft and related trades workers & 0.099 & 0.111 & -0.036 & 0.074 & -0.314 & 0.032 \\
\hline Plant and machine operators & 0.086 & 0.046 & -0.185 & 0.091 & -0.275 & 0.033 \\
\hline Elementary occupations & 0.026 & 0.062 & -0.194 & 0.097 & -0.428 & 0.041 \\
\hline \multicolumn{7}{|c|}{ Industry (agriculture omitted): } \\
\hline Manufacturing of products & 0.079 & 0.147 & 0.203 & 0.082 & 0.271 & 0.060 \\
\hline
\end{tabular}




\begin{tabular}{|c|c|c|c|c|c|c|}
\hline Construction or energy & 0.082 & 0.085 & 0.228 & 0.087 & 0.304 & 0.063 \\
\hline Wholesale or retail trade & 0.052 & 0.137 & 0.107 & 0.088 & 0.188 & 0.061 \\
\hline Hotels and restaurants & 0.015 & 0.037 & -0.014 & 0.116 & 0.076 & 0.075 \\
\hline Transportation and communication & 0.069 & 0.056 & 0.249 & 0.090 & 0.323 & 0.063 \\
\hline Finance, real estate & 0.040 & 0.041 & 0.224 & 0.093 & 0.306 & 0.069 \\
\hline Public administration & 0.147 & 0.073 & 0.182 & 0.082 & 0.195 & 0.062 \\
\hline Education & 0.135 & 0.104 & 0.116 & 0.086 & 0.158 & 0.066 \\
\hline Health and social work & 0.221 & 0.108 & 0.097 & 0.082 & 0.204 & 0.063 \\
\hline Professional services (e.g. legal) & 0.122 & 0.140 & 0.117 & 0.084 & 0.263 & 0.062 \\
\hline Cultural activities (including sport) & 0.020 & 0.041 & -0.009 & 0.106 & 0.088 & 0.066 \\
\hline \multicolumn{7}{|c|}{ Work status (employee in private firm omitted): } \\
\hline Employee in public sector or non-profit & 0.498 & 0.295 & 0.023 & 0.033 & 0.028 & 0.023 \\
\hline Self-employed with employees & 0.035 & 0.033 & 0.182 & 0.092 & 0.208 & 0.062 \\
\hline Self-employed without employees & 0.083 & 0.081 & 0.010 & 0.061 & -0.059 & 0.046 \\
\hline
\end{tabular}

Note: The table reports the mean of the variables for licensed and non-licensed workers in columns 1 and 2. Columns 3 and 4 report the coefficients and standard errors of a wage regression for licensed workers. Columns 5 and 6 report the coefficients and standard errors of a wage regression for non-licensed workers. Individuals in the process of obtaining a license or certification are classified as unregulated. Country fixed effects are included in the regression but their estimated coefficients are not reported. Number of obs. $=15951$. 
Table 11. Oaxaca-Blinder decomposition results.

\begin{tabular}{|c|c|c|c|c|}
\hline & (1) & (2) & (3) & (4) \\
\hline & Estimated values & s.e. & $\mathrm{t}$ & Proportion of total \\
\hline \multicolumn{5}{|l|}{ Differential } \\
\hline Predicted log wage licensed & 2.1710 & 0.0192 & 112.79 & \\
\hline Predicted log wage non-licensed & 2.0766 & 0.0108 & 191.57 & \\
\hline Difference & 0.0944 & 0.0221 & 4.27 & $100 \%$ \\
\hline \multicolumn{5}{|l|}{$\begin{array}{l}\text { Explained composition effects } \\
\text { attributable to }\end{array}$} \\
\hline Union & 0.0022 & 0.0017 & 1.32 & \\
\hline Age & 0.0141 & 0.0033 & 4.24 & \\
\hline Work experience & 0.0130 & 0.0027 & 4.73 & \\
\hline Gender & 0.0043 & 0.0026 & 1.69 & \\
\hline Education & 0.0035 & 0.0042 & 0.84 & \\
\hline Occupation & 0.0093 & 0.0048 & 1.95 & \\
\hline Industry & 0.0028 & 0.0056 & 0.5 & \\
\hline Work status & 0.0060 & 0.0048 & 1.26 & \\
\hline Country & 0.0032 & 0.0157 & 0.2 & \\
\hline Total & 0.0585 & 0.0183 & 3.2 & $62 \%$ \\
\hline \multicolumn{5}{|l|}{$\begin{array}{l}\text { Unexplained wage structure effect } \\
\text { attributable to }\end{array}$} \\
\hline Union & -0.0191 & 0.0103 & -1.85 & \\
\hline Age & -0.1656 & 0.0660 & -2.51 & \\
\hline Work experience & 0.0230 & 0.0272 & 0.85 & \\
\hline Gender & -0.0181 & 0.0168 & -1.08 & \\
\hline Education & -0.0308 & 0.0766 & -0.4 & \\
\hline
\end{tabular}




\begin{tabular}{lcccc} 
Occupation & 0.1405 & 0.0624 & 2.25 \\
Industry & -0.0765 & 0.0944 & -0.81 & \\
Work status & 0.0025 & 0.0223 & 0.11 & \\
Country & -0.0070 & 0.0374 & -0.19 & \\
Constant & 0.1871 & 0.1641 & 1.14 & \\
\cline { 2 - 5 } Total & 0.0359 & 0.0150 & 2.4 & $38 \%$ \\
\hline
\end{tabular}

Note: The table uses non-licensed workers as reference group. The estimated coefficients and mean values of the variables are reported in Table 10. Robust standard errors are reported in column 2. 
Table 12. Licensing and wage inequality: aggregate decomposition results.

\begin{tabular}{|c|c|c|c|c|c|c|c|c|}
\hline & (1) & (2) & (3) & (4) & (5) & (6) & (7) & (8) \\
\hline & sd & var & p99-p1 & p95-p5 & p90-p10 & p50-p5 & p95-p50 & Median \\
\hline Licensed workers & 0.8587 & 0.7373 & 3.7806 & 2.8323 & 2.2314 & 1.4093 & 1.4230 & 1.9816 \\
\hline Non-licensed workers & 0.8456 & 0.7150 & 3.6706 & 2.7061 & 2.2126 & 1.3481 & 1.3581 & 1.8405 \\
\hline Counter factual & 0.8738 & 0.7635 & 3.8305 & 2.8798 & 2.2601 & 1.4193 & 1.4605 & 1.8717 \\
\hline Total effect & 0.0131 & 0.0224 & 0.1099 & 0.1262 & 0.0187 & 0.0612 & 0.0650 & 0.1412 \\
\hline Composition effect & -0.0151 & -0.0261 & -0.0500 & -0.0475 & -0.0287 & -0.0100 & -0.0375 & 0.1099 \\
\hline Wage structure effect & 0.0282 & 0.0485 & 0.1599 & 0.1737 & 0.0475 & 0.0712 & 0.1024 & 0.0312 \\
\hline
\end{tabular}

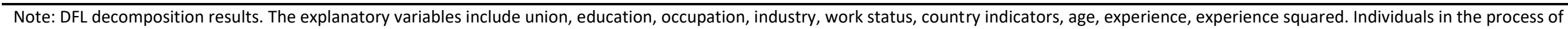
obtaining a license or certification are classified as unregulated. 


\section{FIGURES}

Figure 1. The proportion of licensed workers in the EU.

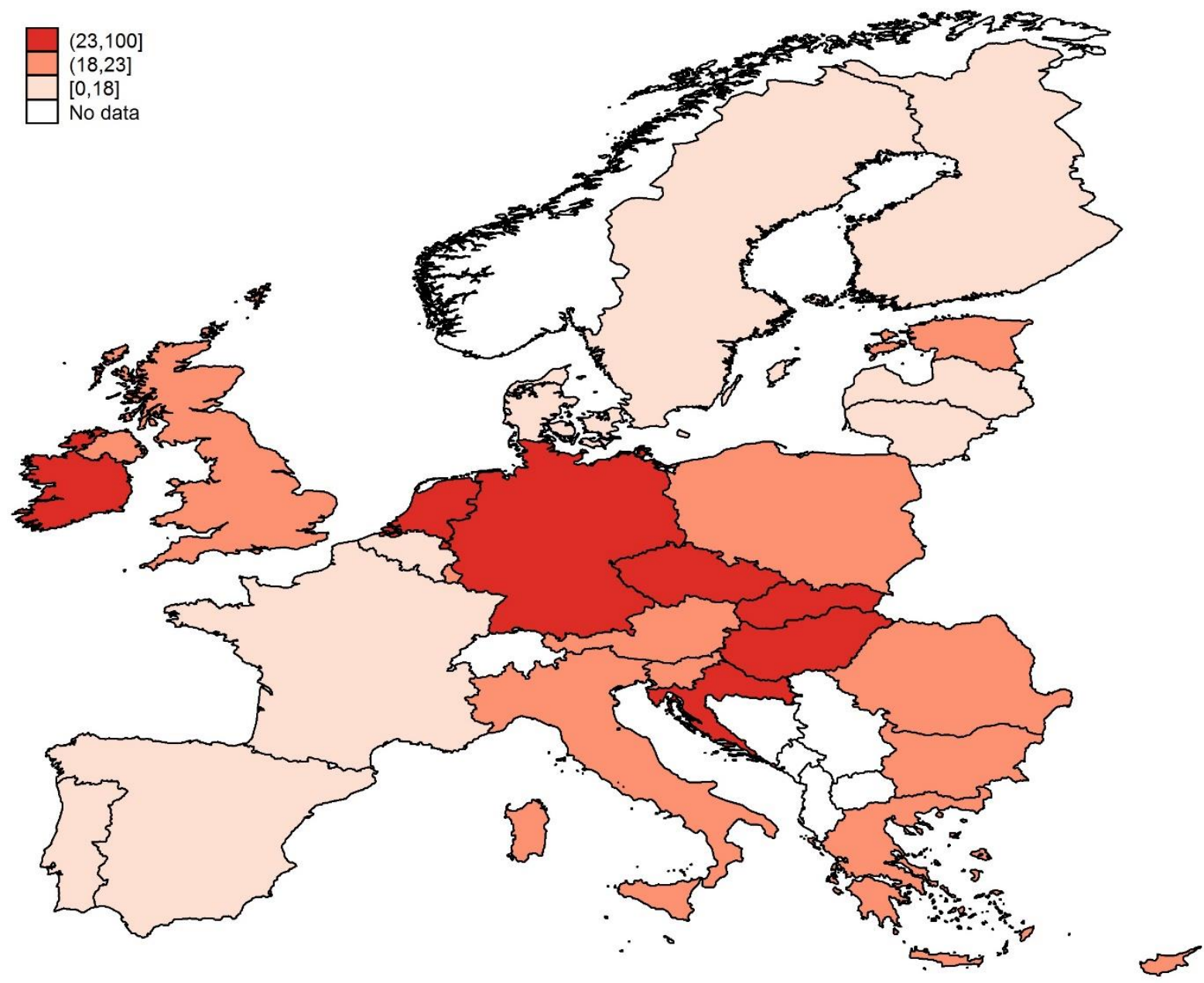


Figure 2. The wage effects of licensing and certification by education.

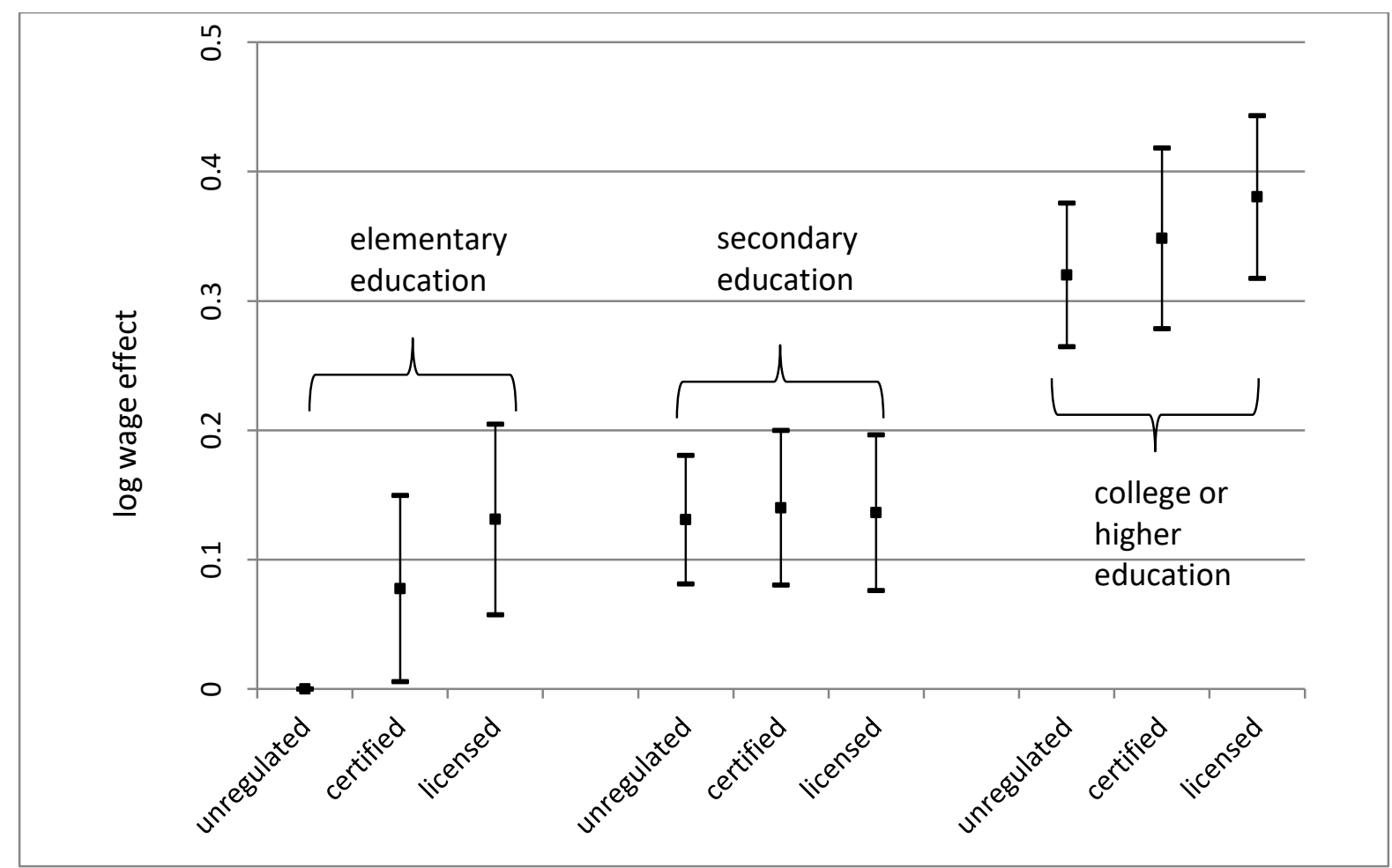

Note: Figure reports the wage effects (computed using estimates in Table 9) of licensing and certification relative to unregulated workers for workers with elementary or lower secondary education, upper secondary and tertiary (noncollege) education, and college or higher. The wage effect of unregulated workers with elementary education is used as reference and it is normalized to zero. Squares correspond to point estimates and bars represent the 95 percent confidence intervals. 
Figure 3. Log wage distribution for licensed and non-licensed workers.



Figure 4. The composition effect on the log wage distribution.

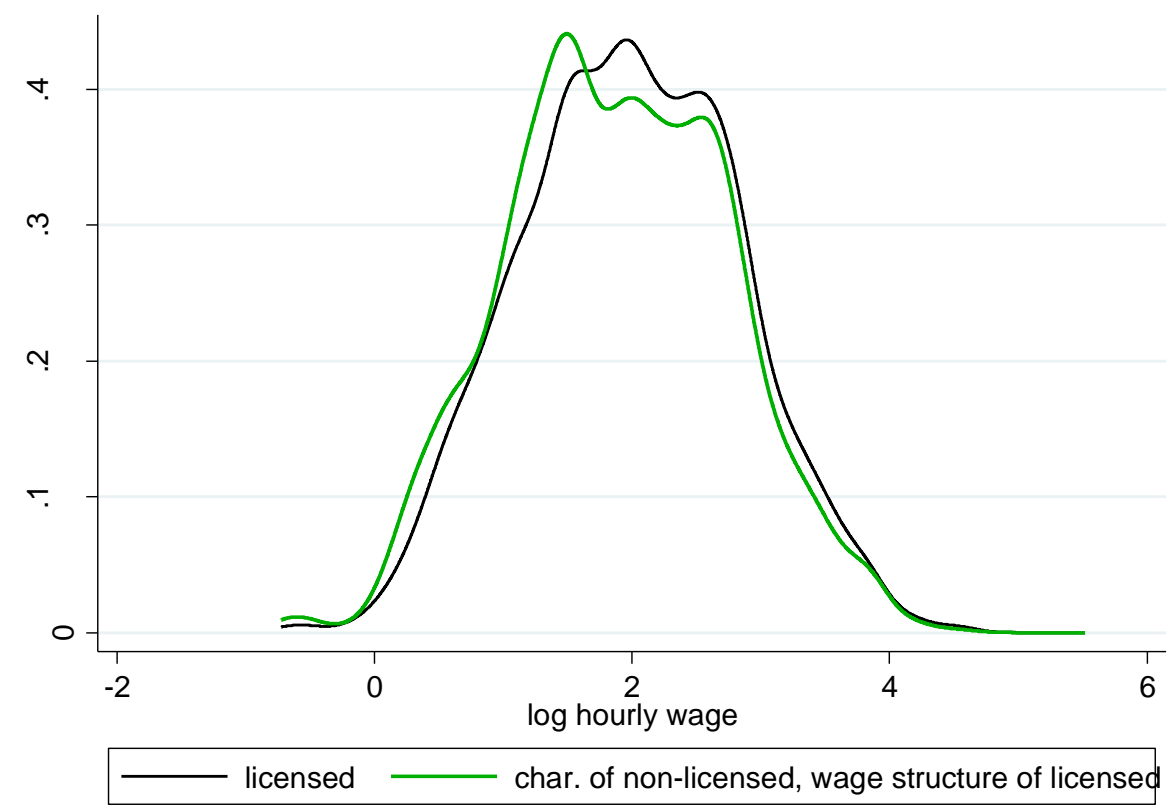


Figure 5. The wage structure effect on the log wage distribution.

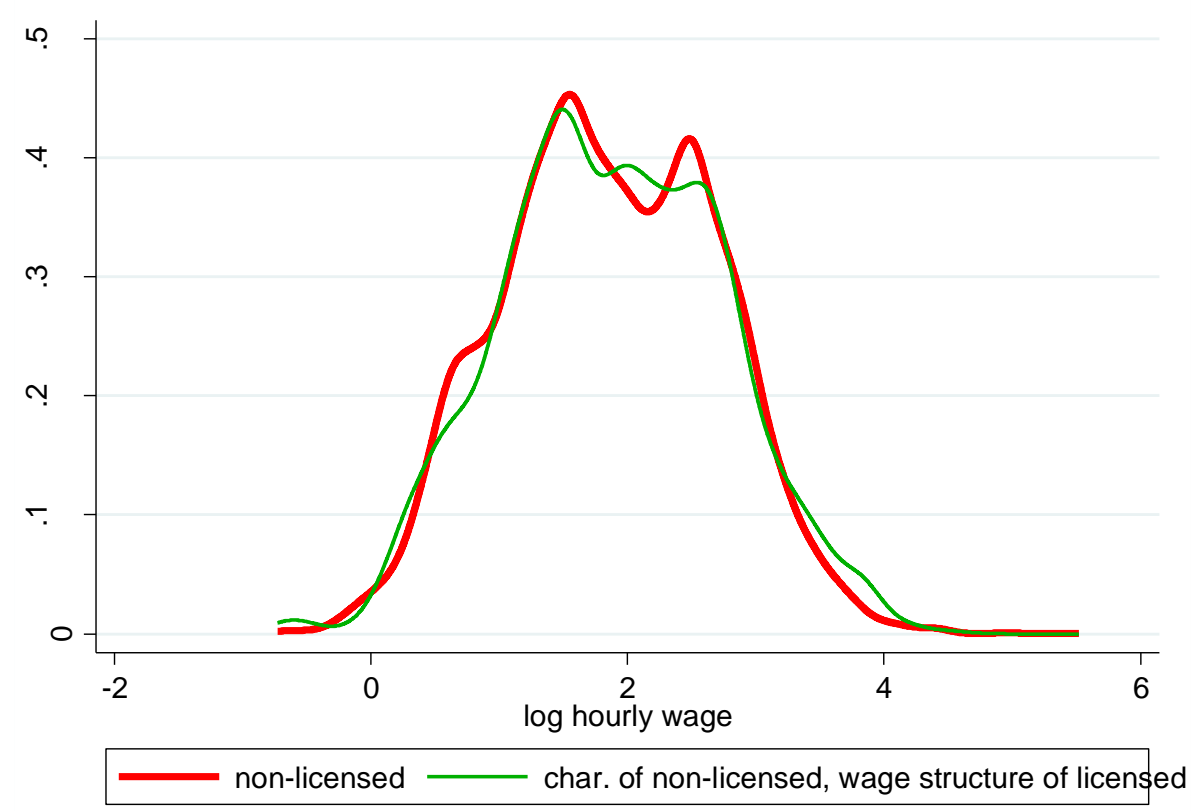

\section{Endnotes}

'The number of interviews is about 1,000 for each country, but 500 for smaller countries like Cyprus, Luxembourg, and Malta.

ii For all countries surveyed, a national weighting procedure using marginal and intercellular weighting was carried out based on a comparison between the sample and the universe. The universe description was derived from Eurostat population data or from national statistics offices. In all countries, gender, age, region and size of locality were introduced in the iteration procedure. For international weighting (i.e. EU averages), the official population figures as provided by Eurostat or national statistic offices were used.

iii The educational attainment level is coded according to the International Standard Classification of Education (ISCED 2011) for each member state (for more information see UNESCO site:

http://www.uis.unesco.org/Education/Pages/international-standard-classification-of-education.aspx).

iv Respondents were asked "Was a minimum level of education required in order to apply for this license?" responses were coded according to the International Standard Classification of Education (ISCED 2011) for each Member state (for more information see UNESCO site:

http://www.uis.unesco.org/Education/Pages/international-standard-classification-of-education.aspx). A 'no minimum level of education required' category was included in the responses.

$\checkmark$ The database is compiled and maintained by the European Commission and it is accessible via this link: http://ec.europa.eu/growth/tools-databases/regprof/index.cfm?action=map_regulations 